\title{
Česká média a zahraniční politika: v hradním stínu a zajetí emocí
}

\author{
Vlastimil Nečas, Lenka Vochocová ${ }^{1}$
}

\begin{abstract}
Czech Media and Foreign Policy: Emotions and Domestic Narratives
On the basis of the analysis of news content from 2008 to 2012, we describe in this article the tendencies of Crech media in dealing with foreign policy topics, using a combination of quantitative content analysis and qualitative case studies of selected foreign policy events. Both quantitative and qualitative analyses demonstrate that the coverage of political events in the media is highly personalised and viewed through the prism of the personal or political interests of $C_{\text {zech }}$ political elites and the conflicts between them. As concerns the diversity of the actors presented and topics covered, the Czech media produce a considerably restricted and more or less uniform stream of news commented upon by a relatively limited spectrum of actors, mainly Czech politicians. For non-political, non-governmental, and international actors, access to the debate is considerably limited. The print media tends to present major political events as power-based conflicts between individuals or groups, rather than as negotiations about public affairs supported by substantive arguments. In effect, Habermas's classical vision of the role of mass media in democracy, which is to promote rational discussion as a desirable form of public debate, is replaced with persuasion through emotional appeal, which has been widely criticised. At the same time, however, some theoretical traditions see it more positively as a less restrictive form of public discourse.
\end{abstract}

Keywords: Foreign Policy, News Media, Agenda Building, Framing, Personalisation, Content Analysis

\section{1. Úvod}

Mediovaná politická komunikace je oblastí, v nîž se významně protíná zájem politologie a mediálních studií. Jűrgen Habermas, klasik teorií veřejné sféry, přisuzuje médiím zásadní roli v koncepci veřejné sféry, která stojí „na okraji politického systému“. Skrze jejich obsahy (,informační, polemické, vzdělávací nebo zábavní) se různí aktéři („politici a politické strany, lobisté a nátlakové skupiny nebo aktéři občanské společnosti“) pokoušejí prosazovat své postoje a zájmy, přičemž média do tohoto procesu vstupují aktivní selekcí hlasů a témat a jejich přetvářením a kontextualizací (Habermas 2006). Podobně McCombs a Shaw v roce 1972 ve své přelomové studii Chapel Hill poukázali na význam zprostředkovatelské role médií v politické komunikaci: „Informace v masových médiích se pro mnoho lidí stávají jediným kontaktem, který s politikou mají. Př́sahy, sliby a rétorika vtělené do zpravodajských př́iběhů, sloupků a úvodníků utvářejí velkou část informací, na jejichž základě dochází k volebnímu rozhodnutí. Většina $\mathrm{z}$ toho, co lidé vědí, $\mathrm{k}$ nim přichází z ,druhé nebo ,třetí ruky“ prostřednictvím masových médií nebo od jiných lidi““ (McCombs a Shaw 1972). Zpravodajská média přitom předkládají události selektivně a konečné obsahy jsou výsledkem vědomých, typizovaných a rutinních procesů (McCombs 2009; Nečas 2006; Shoemaker 1989; Shoemaker a Reese 1996; Gerbner 2002).

\footnotetext{
${ }^{1}$ Vlastimil Nečas, odborný asistent, Fakulta sociálních věd Univerzity Karlovy v Praze, Institut komunikačních studií a žurnalistiky, Katedra mediálních studií. Smetanovo nábřeži 6, Praha 1, 11000 (necas@fsv.cuni.cz). Lenka Vochocová, výzkumná a pedagogická pracovnice, Fakulta sociálních věd Univerzity Karlovy v Praze, Institut komunikačních studií a žurnalistiky, Katedra mediálních studií. Smetanovo nábřeží 6, Praha 1, 11000 (vochocov@fsv.cuni.cz).
} 
V tomto kontextu usilujeme v předkládaném textu o postižení toho, jakými způsoby vybraná česká média konstruují význam zahraničně-politických událostí a roli České republiky v nich a do jaké míry je ve sledovaných obsazích možné identifikovat výše nastíněné trendy. Zjišt’ujeme jednak kvantitativně, o kterých zahraničně-politických tématech hlavní zpravodajské relace tř́ celoplošných českých televizních stanic informují nejčastěji a kteři aktéři české zahraniční politiky v nich dostávají nejvíce prostoru. $\mathrm{V}$ kvalitativních analýzách se pak dlouhodobě zaměřujeme na obsahy hlavních tištěných médií (deníků a týdeníkůª z hlediska výskytu dominantních rámců, jimiž média zdůrazňují určité aspekty událostí a jež mají nezřídka podobu „,velkých narativư“ (bipolární rozdělení světa na sféry vlivu nebo závislé postavení malého českého národa $\mathrm{v}$ srdci Evropy). Sledujeme také role, které média prrisuzují aktérům událostí. Zajímá nás tedy zejména převažující „zahraničně-politický diskurz“ v obsazích klíčových tištěných médií a to, jak se na jeho podobě podílejí dominantní způsoby rámcování událostí. Vyjádřeno parafrází konstatování Bernarda Cohena v knize The Press and Foreign Policy - jelikož síla médií spočívá v definování a kontextualizaci témat, která jsou prezentována jako důležitá, zaměřujeme se na dekonstrukci způsobů, kterými média svým př́jemcům nabízejí, o čem (a v jakých souvislostech) by měli ve vztahu k české zahraniční politice přemýšlet (Cohen 1965: 13).

Následující sekce nabízí souhrn základních teoretických a výzkumných konceptů, které vymezují východiska a cíle navazujících dvou analytických sekcí. Třetí sekce shrnuje výsledky frekvenční analýzy televizního vysílání zaměřené na hlavní témata a prítomné aktéry ve zpravodajství, čtvrtá se soustřed'uje na identifikaci mediálních rámců a kontextualizací v obsazích tištěných médií, které byly navázány na mediálně exponované zahraničně-politické události. V závěrečné sekci formulujeme společné charakteristiky a trendy ve zpravodajství o zahraničně-politických událostech v českých médiích.

\section{Teoretické pozadí výzkumu}

Jak již implicitně plyne z úvodních poznámek, v tomto textu navazujeme na konstruktivistickou tradici uvažování o médiích ${ }^{3}$, podle níž média a novináři vytvářejí, spiše než odrážejí skutečnost (Tuchman 1978). Z konstruktivistických základů vychází i mnoho komunikačních teorií a modelů distribuce informací ve společnosti - blíže viz Berger (1999), Reifová (2004: 106-111). Za klíčové koncepty, které konstituovaly a stále ovlivňují mediální studia i komunikační výzkumy obecně, můžeme označit koncept Spirály mlčení německé socioložky Elizabeth Noelle-Neumann (1993) nebo koncept nastolování agendy (agenda-setting). Základem výzkumů nastolování agendy je hledání vztahu mezi nastavením mediálních obsahů a preferencemi veřejnosti a tvrzení, že média mají schopnost formovat postoje veřejnosti tím, že určují prioritu témat, která $\mathrm{v}$ důsledku

\footnotetext{
${ }^{2}$ Vysvětlení výběru médií viz níže v metodologické části. Bibliografické odkazy na jednotlivé texty jsou uváděny průběžně v poznámkách pod čarou a vědomě se tak vymykají redakčním standardům Středoevropských politických studií. Důvodem je značné množství odkazů a přehlednější orientace čtenáře v textu a př́padné snazší dohledání primárních zdrojů.

${ }^{3} \mathrm{~V}$ politické komunikaci, podobně jako v mediálních studiích a sociálních vědách obecně, můžeme identifikovat dva základní př́stupy ke zkoumání masových médií - objektivistický a konstruktivistický. V souladu s většinou objektivistických teorií považuje tzv. objektivní žurnalistika zprávy (news) za objekty v reálném světě, které existují nezávisle na mediálních organizacích. Prací novináře je hledat tyto zprávy a objektivně je zaznamenávat. Samožrejmým postupem je vyloučení subjektivních vlivů pomocí kontrolních provozních mechanismů v redakcích. Výsledkem takové činnosti by pak měla být co nejpřesnější reflexe reality. V této souvislosti bývá často použivána metafora médií jako zrcadla světa a společnosti. Tyto představy jsou hojně kritizovány mimo jiné (Crossley a Roberts 2004) z pozic konstruktivistických teorií, z nichž vychází také naše studie.
} 
veřejnost považuje za důležitá (McCombs 2009; Nečas 2006; Shoemaker 1989; Shoemaker a Reese 1996; Gerbner et al. 2002). ${ }^{4}$

V tomto kontextu je také vhodné číst výsledky analýzy a obecné závěry, které prezentujeme dále. Ačkoliv se věnujeme pouze analýzám mediálních obsahů, lze předpokládat přenos stereotypů a mediální agendy obecně do agendy veřejnosti, a to zejména u témat, se kterými veřejnost nemá přímou zkušenost (McCombs 2009; Wanta 1997). Tím rozhodně nenaznačujeme, že by média měla schopnost př́mo ovlivňovat preference a názory veřejnosti, nicméně výše zmíněné teorie potvrzují schopnost médií nastolovat témata, tedy diskurzivní pole a sémantické rámce, které veřejnost následně akcentuje, označuje za důležité a pod jejichž vlivem se př́padně rozhoduje. S nastolováním agendy úzce souvisejí také př́ístupy zaměřující se na analýzu rámců (frame analysis), tedy na identifikaci těch aspektů událostí, které média vybírají a zdůrazñují ve svém informování. Rámce přitom mohou naznačovat jak to, koho média dominantně zobrazují jako hlavní aktéry událostí, komu přisuzují v konfliktech např́klad roli viníka/agresora a naopak oběti, tak také osvětlovat, jak jsou jednotlivé události provazovány (aktualizace rámců, nesouvisejících témat), které aspekty událostí jsou prezentovány jako podstatné nebo které narativy v reprezentacích událostí převažují (de Vreese 2005; Entman 2004; Johnson-Cartee 2005; Reese, Gandy a Grant 2001).

V logice výše nastíněného př́stupu se nesoustředíme na důvody či mechanismy mediální selekce politických událostí, ale zajímá nás, jak zpravodajská média „budují agendu“ a jak zahraničně-politické události kontextualizují. V žádném případě nevztahujeme výsledné mediální obsahy ke „skutečnému stavu věci“", nesrovnáváme podobu mediální agendy s „realitou“ událostí, o kterých média referují (Funkhouser 1973), ani nevyjadřujeme soudy (v konstruktivistickém př́stupu nerelevantnî) týkající se toho, zda jsou média „pravdivým zrcadlem“ světa, politiky nebo veřejného mínění. Zajímají nás pouze obsahy, které zpravodajská média předkládají veřejnosti. Stejně tak, ačkoli své výsledky samožrejmě vztahujeme k závěrům oborové literatury, která identifikuje převažující tendence médií jako aktérů politické komunikace (viz níže), nejsme zastánci normativních pozic, podle nichž existují žádoucí a méně žádoucí, či prúmo nežádoucí způsoby referování o politických událostech. Za negativní bývají z těchto pozic často považovány zejména personalizace ${ }^{5}$, odklon od racionální debaty $\mathrm{k}$ emocím, herním prvkům, príběhům a akcentaci střetů a negativity v politické diskusi (Blumler a Kavanagh 1999; Holtz-Bacha 2004; Karvonen 2010; Kinder 1994; Mazzoleni a Schulz 1999; Vliegenthart, Boomgaarden a Boumans 2010).

V duchu normativní habermasovské kritiky veřejného diskurzu v médiích (Habermas 2000) bychom tedy mohli mluvit o odklonu od informační role médií, která by měla tříbit názory

\footnotetext{
${ }^{4} \mathrm{~K}$ vlivu masmédií na volební chování a politické rozhodování veřejnosti viz např. Lazarsfeldův výzkum People’s Choice (Lowery a DeFleur 1995: 69-92), Chapel Hill Study (McCombs a Shaw 1972) či monografii Framing Europe Claese deVreese (2005).

${ }^{5}$ Personalizaci ve smyslu zaměření obsahu na jednotlivé politiky jako klíčové politické aktéry Van Aelst et al. (2012) nazývají individualizací. Ta podle nich „nutně nekontrastuje se zásadním politickým zpravodajstvím, ale naznačuje odklon od mediálního zájmu o politické strany směrem k jednotlivým politikům nebo od vlády k jednotlivým členům kabinetu“ (Van Aelst et al. 2012: 205) Autoři však upozorňují i na druhou formu personalizace, která zahrnuje posun mediálního zájmu z politiků jako představitelů veřejné role k politikům jako soukromým osobám bez souvislosti s jejich veřejnou rolí - nazývají ji privatizací (Van Aelst et al. 2012: 205). Pojetí personalizace jako „privatizace“ u Van Aelsta et al. (2012) koresponduje s distinkcí Frantové mezi personalizací a celebritizací: „Na rozdíl od procesu personalizace nemá zpravodajství o politicích jako celebritách [v originále „,elebrity-news about politicians“ - pozn. aut.] jakýkoli vztah k veřejné pozici, kterou reprezentují. Média prostě jen využívají pozice známých politiků a tato jejich známost jim slouží k dosažení zájmu veřejnosti zakoupit si výtisk novin (Frantová 2010: 2).
} 
občanů a prosazovat názorovou pestrost, k zábavní formě, jejíž funkce je spíše eskapistická. Současně je ovšem nutné upozornit také na významnou tradici ve studiu médií, která zdůrazňuje pozitivní aspekty narativity ve zpravodajských obsazích pro publika nebo význam emocionality pro inkluzivitu veřejné sféry či veřejných sfér (Machill et al. 2007; Marx Ferree et al. 2002; McLaughlin 1993, 1999; Richards a Rees 2011; Zoonen 2004). Machill tak např́ílad zdůrazňuje význam narativních prostředků v televizním zpravodajství pro jasněǰš́ chápání zpravodajského obsahu publiky a pro sociální komunikaci obecně, i když současně upozorňuje, že stále více prostoru věnovaného narativitě má i svá úskalí, jako jsou prrilišná zjednodušování (např. nadhodnocování role jednotlivců vlivem personalizace a emocionalizace), tematická nevyváženost (více zábavních témat na úkor těch společensky závažných), tendence přehánět aj. (Machill et al. 2007: 186). Richards a Rees zmiňují „emoční obrat“ ${ }^{\text {‘6 }}$ ve společnosti a upozorňují na význam „emoční veřejné sféry“, která „může mít rozhodující význam v nasměrování politických událostí, ačkoli je často přehlížena“. Podle nich dochází v posledních desetiletích k emocionalizaci veřejné sféry a pro politiky je stále důležitější schopnost „emočního řízení“, tedy promyšlené a informované pozornosti věnované emočním dynamikám veřejnosti. Podle autorů hrají média vedle politiků významnou roli v nastavení „emočního tónu veřejné sféry“ a jak uvádějí, zatímco někteří v emocionalizaci veřejné sféry spatřují úpadek politiky na úroveň mýdlových oper, jiní vnímají význam tohoto trendu jako cesty „k obnovené občanské angažovanosti“ (Richards a Rees 2011: 853). Myra Marx Ferree et al. pak rozlišují „,čtyři tradice demokratických teorií, z nichž každá přináší specifické odpovědi „pro pojetí veřejné sféry a konkrétněji pro mediální diskurz v soudobých demokraciích“. Oproti elitní reprezentaci a expertíze při řešení podstatných veřejných otázek, které jsou podle nich prosazované tradicí zastupitelské liberální teorie, vyzdvihují spíše širší, celospolečenskou diskusi o věcech veřejných a vyloučení širokých vrstev společnosti (s poukazem na jejich neexpertnost) odmítají. Zdůrazňují přitom také omezující roli požadavků týkajících se ideální podoby veřejného diskurzu v některých tradicích, jakými jsou např́ílad právě emoční odstup a striktně racionální argumentace (Marx Ferree et al. 2002).

\section{Metodologie}

V rámci takto vymezeného výzkumného pole stojí za zdůraznění, že naše analýzy zahraničně-politického zpravodajství v obsazích vybraných českých médií, jejichž závěry souhrnně prezentujeme níže, je třeba považovat za deskriptivní, nikoli hodnotící. V textu tak představujeme souhrn hlavních poznatků týkajících se toho, jak vybraná česká média referují o zahraničně-politických událostech a zejména o př́stupu české zahraniční politiky $\mathrm{k}$ nim. Tyto trendy jsme identifikovali na základě čtyř po sobě následujících analýz mediálních obsahů vztahujících se k zahraniční politice ČR v letech 2008-2011 (Nečas 2009; Nečas a Vochocová 2010, 2011; Vochocová a Nečas 2012). Studie analyzující vždy obsahy publikované v jednom kalendářním roce kombinovaly deskriptivní, kvantitativní analýzu televizního zpravodajství s kvalitativními př́ípadovými studiemi vybraných zahraničně-politických událostí v tištěných periodikách. Dílčí analýzy vznikaly na objednávku Ústavu mezinárodních vztahů, proto poněkud nestandardně kombinují kvantitativní a kvalitativní analýzu odlišných typů mediálních obsahů (audiovizuální obsahy analyzované kvantitativně a kvalitativní př́padové studie tištěných obsahư7). V této stati

\footnotetext{
${ }^{6} \mathrm{~V}$ angl. affective turn.

${ }^{7} \mathrm{~V}$ analýze kombinujeme televizní a tištěná média zejména z důvodu zajištění vyšší pestrosti zkoumané produkce českých zpravodajských médií. U televizního zpravodajství dochází k výraznější redakční selekci při výběru událostí než v případě tištěných médií. Jedna televizní zpravodajská relace obsahuje maximálně jednotky př́ispěvků, zatímco
} 
klademe hlavní důraz na analýzu tištěných médií, která zobecňuje závěry případových studií poskytujících širší možnosti interpretací jednotlivých trendů. Závěry kvantitativních analýz televizního zpravodajství ve velmi zobecněné podobě připojujeme zejména proto, že umožňují získat přehled o významu těchto trendů ve sledovaných letech (např. o míře personalizace v mediálních obsazích nebo o stupni konvergence v rámci hlavních českých televizních stanic).

Čistě popisná, kvantitativní část analýzy se soustředí na identifikaci základních charakteristik sledovaných obsahů, a to na hlavní témata a hlavní přítomné aktéry. Výsledky z jednotlivých let je díky využití identické metody na stejně definovaný vzorek možné vzájemně srovnávat. Zkoumaný vzorek vždy tvoří hlavní zpravodajské relace tř́ českých celoplošných televizních stanic, tedy Události (Česká televize), Televizní noviny (NOVA TV) a Zprávy (TV Prima), $\mathrm{v}$ daném kalendářním roce ${ }^{8}$.

Ve snaze dostat se za explicitní a kvantifikovatelné charakteristiky mediálních obsahů rozšiřujeme každý rok analýzu o kvalitativní textuální rozbor vybraných mediálně výrazně exponovaných událostí (případové studie). Každoročně se věnujeme analýze vybraných témat ve zpravodajství a publicistice Hospodářských novin, Mladé fronty DNES, Práva a týdeníků Ekonom a Respekt ${ }^{10}$. Cílem textuálního rozboru je pojmenovat u jednotlivých témat převládající rámce, hlavní a vedlejší aktéry a role, které jim média přisuzují. Zajímá nás, jak jsou události rámcovány, v jakém kontextu a s jakým důrazem média referují o jednotlivých událostech, jaké argumentační strategie zdůrazňují a především jak konstruují pozici české zahraniční politiky - či obecně České republiky - v mezinárodním kontextu.

Při identifikaci rámců a pozice aktérů jsme u konkrétních témat postupovali na základě prvních dvou stupňu kódování zakotvené teorie (Strauss a Corbin 1999), které nám umožňují

jedno vydání deníku řádově desítky. Na druhou stranu, z hlediska rozboru sémantických rovin, kontextů a rámců obsažených v mediálních sděleních je relevantní zkoumat především zpravodajskou produkci tištěných médií, která autorům nabízí větší prostor pro vyjádření (zejména v př́ípadě názorové publicistiky). Proto se u televizního zpravodajství soustředíme „pouze“ na kvantifikované zachycení prioritních témat a aktérů, zatímco u tištěných médií sledujeme prrítomné narativy, zdůrazněné kontexty a použitá zdůvodnění.

${ }^{8}$ Datovou matici s nakódovanými príspěvky televizního zpravodajství poskytla pro účely této studie společnost Media Tenor (www.mediatenor.cz). Př́spěvky jsou kódovány podle předem dané metodiky kontrolovatelným způsobem a ke kódování obsahu využívá společnost Media Tenor tým proškolených pracovníků. Výsledky práce kodérů podléhají vícestupňové kontrole, což umožňuje dosažení 90 - 95\% shody při kódování (intercoder reliability). Hodnot v proměnné „téma“ v kódovacím formuláŕi je více než 6 tisíc, nicméně vzhledem k zacílení deskriptivní části analýzy dochází k nutné agregaci hodnot do obecnějších kategorií. Báze dat (N) u jednotlivých grafů a tabulek představuje počet výpovědí/příspěvků, které byly zahrnuty do analýzy. Číslo v bázi se nemusí vždy shodovat se součtem hodnot uvedených v grafu, prezentuje-li např́iklad pouze nejvýznamnější výsledky - v našem př́padě u aktérů a destinací, kdy je možné $\mathrm{k}$ jednomu př́spěvku přiřadit vícero aktérů, respektive oblastí. Kategorie „téma“ reprezentuje hlavní téma příspěvku, tedy téma, ke kterému se v rámci příspěvku vztahuje nejvíce výpovědí.

${ }^{9}$ Jednalo se o tyto události/prrípadové studie: V roce 2009: březnový pád české vlády, zářijové rozhodnutí USA zrušit plánovanou výstavbu radarové základny v Česku, listopadový podpis Lisabonské smlouvy. V roce 2010: česká mise v Afghánistánu, podpis smlouvy START II prezidenty Obamou a Medveděvem v Praze. V roce 2011: jmenování státního tajemníka ČR pro evropské záležitosti, krize a záchrana eurozóny a konflikty v arabským zemích označované jako „arabské jaro“. Výběr analyzovaných událostí je výsledkem konzultací s analytickým oddělením Ústavu mezinárodních vztahů, v.v.i.

10 Výběr tištěných médií vychází jednak ze snahy zahrnout do vzorku zástupce celoplošných deníků z různých vydavatelství tradičně zařazovaných mezi seriózní tisk (odtud výběr tř́i uvedených deníků), jednak se zaměřit i na obsahy týdeníků, u nichž je možné předpokládat, že odlišné zpracovatelské rutiny i odlišná periodicita a cíle těchto médií umožňují věnovat více prostoru kontextualizaci a hlubší analýze. Do vzorku však nebyly zahrnuty týdeníky, které se definují jako společenské (Reflex) či zpravodajsko-společenské (Týden). Vzorek tvořily vždy všechny texty publikované ve zpravodajských a publicistických rubrikách daných médií, případně jen v jejich publicistických částech, vybrané za určité období na základě konkrétních klíčových slov ke každému z témat (detailněji $\mathrm{k}$ metodě výběru viz Nečas a Vochocová 2010, 2011 a Vochocová a Nečas 2012). 
induktivní cestou abstrahovat od jednotlivých jevů k obecnějším kategoriím a vztahům mezi nimi, a konceptu rámcování (Vreese 2005; Reese et al. 2001; Reese 2007), jehož prostřednictvím jednotlivé obecné kategorie i jejich subkategorie identifikujeme jako klíčové rámce, jimiž média explicitně či implicitně interpretují zahraničně-politické události. Ačkoli jednotlivé analýzy vznikaly v ročních odstupech, a týkaly se tedy rozdílných témat, podařilo se nám vysledovat určité tendence $\mathrm{v}$ referování o zahraničně-politických událostech jak v hlavních zpravodajských relacích českých celoplošných televizních stanic ( $\mathrm{v}$ kvantitativním smyslu), tak také v mediálních reprezentacích zásadních zahraničně-politických témat v obsazích vybraných českých deníků a týdeníků (v podobě opakovaně se vyskytujících klíčových rámců, jejichž metaanalýzou jsme dospěli $\mathrm{k}$ závěrům předkládaným níže). Zajímavá je také podobnost rámcování událostí napříč tištěnými médii i jejich odlišnými typy (deníky - týdeníky), kterou se nabízí interpretovat jako zřetelnou obsahovou konvergenci českých tištěných médií - výjimkou jsou pouze některé události (např. diskuse o navýšení počtu českých vojáků v Afghánistánu v roce 2010, př́padně vztah k ,ruské hrozběco), kdy zejména deník Právo zaujímá ve srovnání s ostatními analyzovanými médii odlišnou perspektivu (detailněji viz Nečas a Vochocová 2010, 2011 a Vochocová a Nečas 2012). Z výše uvedeného vyplývá, že je možné identifikovat opakující se postupy, kterými česká média referují o politických událostech s mezinárodním dopadem, a podílejí se tak na podobě a vývoji zahraničně-politického diskurzu v České republice.

\section{Zahraničně-politické zpravodajství českých TV stanic}

Kvantitativní obsahová analýza českého televizního zpravodajství se soustředí na stručný popis dvou hlavních charakteristik, na hlavní témata a nejčastěji př́tomné aktéry. Trendy ve vývoji hlavní agendy médií ve vztahu k zahraničně-politickým tématům nejsou zcela jednoznačné - je zřejmé, že hlavní témata, která dominovala zahraničně-politickému zpravodajství českých televizí, jsou z části ovlivněna aktuálními událostmi v daných letech. Přesto je možné identifikovat klíčové tendence týkající se výběru témat a preferování konkrétních aktérů u jednotlivých událostí. Mezi předními tématy posledních čtyř let se stabilně objevují vztahy ČR k EU v kontextu hospodářské politiky a další integrace $\mathrm{v}$ rámci EU. Ostatní prioritní témata jsou poplatná aktuálním, často mediálně vděčným a zpravodajsky exponovaným událostem, jako jsou zahraniční návštěvy nebo kontroverze ohledně budování radarové základny v Brdech. Pokud existují nějaká střednědobá strategická témata české zahraniční politiky, která měla být komunikována veřejnosti, pak jsou $\mathrm{v}$ agendě českého zpravodajství př̀kryta jinými, mediálně atraktivnějšími tématy. 
Tab. č. 1: Hlavní témata zahraničně-politického zpravodajství českých TV stanic v 1. 2008-2011.

\begin{tabular}{|c|c|}
\hline \multicolumn{2}{|l|}{2008} \\
\hline obranný systém (radar) & 224 \\
\hline integrace EU & 130 \\
\hline předsednictví ČR Radě EU & 74 \\
\hline zahraniční mise Armády ČR & 64 \\
\hline vztahy ČR-USA & 60 \\
\hline \multicolumn{2}{|l|}{2009} \\
\hline integrace EU & 176 \\
\hline zahraniční návštěvy & 68 \\
\hline zahraniční politika EU & 63 \\
\hline předsednictví ČR Radě EU & 63 \\
\hline obranný systém (radar) & 60 \\
\hline \multicolumn{2}{|l|}{2010} \\
\hline zahraniční návštěvy & 45 \\
\hline zahraniční mise Armády ČR & 43 \\
\hline ekonomika EU & 36 \\
\hline humanitární pomoc & 35 \\
\hline EXPO Šanghaj & 18 \\
\hline \multicolumn{2}{|l|}{2011} \\
\hline ekonomika EU & 45 \\
\hline zahraniční návštěvy & 33 \\
\hline vztahy ČR-EU & 30 \\
\hline mezinárodní vztahy obecně & 28 \\
\hline vztahy ČR-USA & 24 \\
\hline
\end{tabular}

Zdroj: autoři

Z hlediska aktérů vykazuje zahraničně-politické televizní zpravodajství ve sledovaných letech značnou personalizaci, především redukci variety možných mluvčích na několik českých politických elit. Mezi sledovanými stanicemi také dochází $\mathrm{k}$ výrazné shodě při identifikování nejdůležitějších aktérů zahraniční politiky. Ve výrazné většině případů se jedná o vrcholné politiky českého státu, především prezidenta, současné či minulé premiéry (P. Nečas, J. Fischer, M. Topolánek), předsedy nejsilnější opoziční strany ČSSD a prezidenty velmocí, kteří ve sledovaném období navštívili ČR (B. Obama, D. Medvědev). Možnost překročit práh mediální pozornosti je tak značně omezená pro zástupce občanské společnosti, odborné veřejnosti, zahraniční aktéry a mnoho dalších myslitelných aktérů. ${ }^{11}$

\footnotetext{
${ }^{11}$ V r. 2011 dochází k řádovému poklesu množství reportáží věnovaných zahraniční politice, a to při použití stejných výběrových kritérií jako $\mathrm{v}$ předchozích letech. Interpretace takto dramatického poklesu př́ispěvků bude možná až v kontextu dat získaných za r. 2012.
} 
Tab. č. 2: Hlavní aktéři českého zahraničního televizního zpravodajství v 1. 2008-2011 (N=12 920)

\begin{tabular}{|c|c|}
\hline \multicolumn{2}{|l|}{$2008(N=3024)$} \\
\hline Topolánek M. & 296 \\
\hline Klaus V. & 173 \\
\hline Paroubek J. & 134 \\
\hline Schwarzenberg K. & 117 \\
\hline Vondra A. & 89 \\
\hline \multicolumn{2}{|l|}{$2009(\mathrm{~N}=4632)$} \\
\hline Klaus V. & 358 \\
\hline Topolánek M. & 340 \\
\hline Fischer J. & 202 \\
\hline Paroubek J. & 199 \\
\hline Obama B. & 135 \\
\hline \multicolumn{2}{|l|}{$2010(\mathrm{~N}=4632)$} \\
\hline Klaus V. & 138 \\
\hline Nečas P. & 98 \\
\hline Fischer J. & 80 \\
\hline Obama B. & 74 \\
\hline Schwarzenberg K. & 50 \\
\hline \multicolumn{2}{|l|}{$2011(\mathrm{~N}=632)$} \\
\hline Nečas P. & 132 \\
\hline Klaus V. & 123 \\
\hline Schwarzenberg K. & 94 \\
\hline Kolář V. & 55 \\
\hline Medveděv D. & 38 \\
\hline
\end{tabular}

Zdroj: autoři

Bez ohledu na specifika jednotlivých let se ukazuje, že sledované konkurenční televizní stanice vykazují vysokou míru shody u témat i aktérů. Z pohledu analýzy objemnějších datových souborů a delších časových období vyplývá, že komerční televize i televize veřejné služby předkládají divákům víceméně stejné mediální př́iběhy se stále stejnými herci (Goffman 1963). Tento trend lze interpretovat $\mathrm{v}$ zásadě dvěma způsoby. V souladu s tzv. reflexivními teoriemi médií můžeme tvrdit, že média reagují stejným způsobem na mimomediální realitu, na „reálně“ důležité události, a je tudíž pochopitelné, že se do velké míry shodují v pozornosti věnované důležitým událostem. Z pohledu výzkumů nastolování agendy se ale zpravodajská média při výběru zpráv neř́dí vnějšími okolnostmi, závažností událostí, ale spíše tím, zda je daná událost mediálně atraktivní, tzv. zprávotvorná (newsworthy), a jestli je také zdůrazňována ostatními médii (tiskovými agenturami a důležitými médii, koncept tzv. intermediální agendy). Výběr událostí, ze kterých jsou následně vytvářeny zprávy, je tak podřízen spíše vnitřním mechanismům mediálních organizací než reálné důležitosti událostí (Funkhouser 1973; McCombs 2009; Trampota a Nečas 2007; Weaver et. al 1998). 


\section{Zahraniční politika v českém tisku}

V průběhu tři let (2009-2011) jsme realizovali prrípadové studie $\mathrm{k}$ hlavním zahraničně-politickým tématům daného roku na základě kvalitativní analýzy zpravodajských a publicistických textů čtyř celoplošných deníků a dvou týdeníků vycházejících v ČR. Jednalo se o nejvýznamnější události zahraniční politiky nebo výjimečně takové domácí události, které kontextově získaly rozměr událostí mezinárodních (takovým př́padem byl pád vlády v roce 2009 během předsednictví ČR v Radě EU). V analýze neoddělujeme výsledky vztahující se k publicistickým útvarům (komentáře, rozhovory) od zpravodajských, protože se zaměřujeme na postižení obecného zahraničněpolitického diskurzu ve sledovaných médiích, v nichž se zpravodajské i publicistické texty svým charakterem výrazně sbližují. Podle očekávání jsou v komentářových textech některé z námi vysledovaných tendencí nápadnějšśi, nicméně závěry jsou platné i pro texty zpravodajské; v určitém smyslu tedy můžeme mluvit o stírání rozdílu mezi informací a názorem. Texty ve sledovaných letech vykazují společné charakteristiky, z nichž je možné vyvozovat trendy v referování o zahraničně-politických událostech v českých tištěných médiích (a řada výsledků rezonuje také s kvantitativními daty vztahujícími se ke zpravodajství celoplošných televizních stanic).

Přestože celkově analyzovaná média představují témata poměrně komplexně (z hlediska fakticity a relevance informací a př́tomnosti odborných hlasů), vztah české zahraniční politiky k mezinárodním tématům je reprezentován velmi specificky. O zahraničně-politických postojích a rozhodnutích je referováno jako o záležitosti jednotlivých politických představitelů (personalizace) a velmi nápadnou strategií, kterou jsme identifikovali u většiny sledovaných témat, je vytváření př́měrů $\mathrm{k}$ historickým událostem, jejichž dopad pro české země je možné definovat jako traumatický (oblíbené „osmičkové“ roky: 1848, 1938, 1948, 1968). Politický diskurz na stránkách deníků a týdeníků je silně polarizovaný a využívá metaforického jazyka a konfliktnosti, které posilují emotivní vyznění textů. Média prostřednictvím těchto nástrojů, společně s politiky, kteři často sami formulují tyto historické paralely i ostatní metafory, jež média reprodukují a udržují v agendě, konstruují četné hrozby pro českou společnost, př́padně mezinárodní společenství. Odkazy k historickým křivdám, válkám, omezením národní suverenity, zneužitím politické moci nebo metafory tragédií jako Titanik tak posilují negativní vyznění mediálních obsahů, potažmo negativní, na emocích vystavěné rámcování zahraničně-politických událostí (srov. s „emočním obratem“ u Richardse a Reese 2011).

\section{5.a Personalizace a konfliktní nastavení: zahraniční politika jako rukojmí vnitropolitických sporů a zájmů}

Při referování o událostech se vztahem k české zahraniční politice vykazovala média vysoký stupeň personalizace, ${ }^{12}$ především pak v duchu individualizace u van Aelsta et al. (2012: 205). ${ }^{13}$ Podstatný je ovšem také výrazně negativní, polarizovaný charakter mediálního zahraničněpolitického diskurzu: zahraniční politika je prezentována jako bitevní pole sloužící k prosazování zájmů či vlivu několika politických subjektů, je explicitně označována za obět' či rukojmí vnitropolitických sporů, ${ }^{14}$ je rámcována jako boj o vliv a moc. Konfliktní vyznění české

\footnotetext{
12 Z teorií politické komunikace viz např. Karvonen 2010, Mazzoleni 2000, McAllister 2007, Swanson and Mancini 1996.

${ }^{13} \mathrm{~K}$ vysvětlení jejich pojetí viz pozn. pod čarou č. 3.

14 Komárek, Martin. 2010. „Afghánistán ano! Ale ne za tuhle cenu.“ s. 10 in Mladá fronta DNES, Názory, 26.10.2010; Soukup, Ondřej. 2010. „Moskva varuje před závody ve zbrojení،“ s. 7 in Hospodářské noviny, Svět,
} 
zahraniční politiky je médii nezrrídka umocněno bojovou terminologií („zůstávají zakopány ve svých pozicích”, „dva největší rivalové”, ,jsou ve válce”) ${ }^{15}$ a její celkově emotivní charakter pak

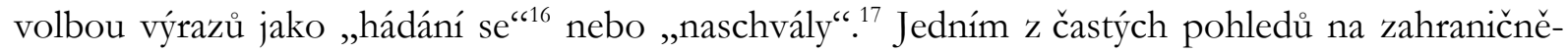
politické události je tedy ve sledovaných médiích jejich rámcování jako konfliktní otázky vnitrostátní politiky ovládané několika znesvářenými jednotlivci a jejich osobními animozitami. Např́klad jmenování dvou úředníků do podobných pozic ve vztahu k Evropské unii (státního/ministerského tajemníka pro evropské záležitosti) v roce 2011 je prezentováno převážně jako konflikt ve vládní koalici, zejména mezi ministrem zahraničí Karlem Schwarzenbergem a premiérem Petrem Nečasem. Rámcování události jako vnitropolitického soupeření či prosazování vlastních politických zájmů je umocňováno také důrazem samotných politiků - prolínání politické a mediální agendy je tedy velmi nápadné, média v mnoha př́padech přejímají politické rámcování událostí. ${ }^{18}$ Také v roce 2009 (v době předsednictví ČR v Radě Evropy) referovala média o pádu vlády premiéra Topolánka prostřednictvím důrazu na několik elitních aktérů, které líčila jako oponenty v de facto nesmiřitelných konfliktech. Silná polarizace zahraničně-politického diskurzu prostřednictvím nesmiřitelnosti pravice a levice vzhledem $\mathrm{k}$ jejich vnitropolitickým zájmům je typická také pro téma možného navýšení počtu českých vojáků na misi v Afghánistánu v roce 2010. Jedním z dominantních způsobů rámcování tématu, stejně jako tématu pádu vlády v roce 2009, je konflikt domácí a zahraniční politiky, a také rozpor mezi expertním posouzením situace a politickými zájmy aktérů.

Klíčovým aktérem většiny sledovaných zahraničně-politických událostí je v mediálních obsazích prezident České republiky Václav Klaus. Média mu přisuzují výrazný vliv na českou zahraniční politiku na různých úrovních ${ }^{19}$ a prrípadové studie tak opakovaně vedou k závěru, že jedním z oblíbených mediálních rámců je prezentace politických událostí jako „one man show“ Václava Klause. V souvislosti s pádem vlády v roce 2009 je tak Klaus označován jako „hlavní hybatel politické krize“, ${ }^{20}$ média spekulují o jeho motivacích přispět k vládní krizi - zdůrazňují zájmy vnitrostranické (Klausův vliv na podobu ODS), vnitrostátní (Klausova možnost ovlivňovat vládu ČR) i rozměr zahraničně-politický (Klausův euroskepticismus a zřejmá proruská

2.12.2010; Komárek, Martin. 2009. „....ale chová se jako salonní vyděrač.“ s. 8 in Mladá fronta DNES, Názory, 13.10.2009.

15 Šídlo, Jindřich, Weikert, Petr. 2009. „Zákopová válka začala.“ s. 1 in Hospodářské noviny, 26.3.2009; „Ostrá hádka Topolánka a Klause“ (vdo). 2009. s. 1 in Mladá fronta DNES, 28.3.2009; Kamberský, Petr. 2009. „Mezi skřety a vlky.“ s. 9 in Hospodářské noviny, Názory, 24.3.2009. Podobně též: Kopecký, Josef. 2009. „Pád vlády.“ s. 1 in Mladá fronta DNES, 25.3.2009.

16 „Hádá se totiž kvưli tomu koalice a Evropa přestává chápat českou zahraniční politiku.“ (Štětka, Jan. 2011. „Dvě tváře pro Evropu.“s. 40 in Ekonom, Politika a byznys, 22.9.2011)

17 Tabery, Erik. 2011. „Vláda naschválů.“ s. 15 in Respekt, Komentáře, 5.9.2011; Rovenský, Jan. 2011. „Nečas a Schwarzenberg se přebíjejí státními tajemníky.“s. 3 in Právo, Zpravodajství, 6.9.2011.

18 Šídlo, Jindřich, Honzejk, Petr. 2011. „Kdyby se tu objevil nějaký Haider, požehnej nám Bůh.“ s. 9 in Hospodářské noviny, Rozhovor, 2.9.2011; „Tajemníka EU vyřeší spolu Nečas a Schwarzenberg“ (dan). 2011. s. 3 in Právo, Zpravodajství, 14.9.2011; „Schwarzenberg jmenoval tructajemníka pro Unii“ (iDNES.cz). 2011. s. 4 in Mladá fronta DNES, Z domova, 5.9.2011; Königová, Marie. 2011. „Schwarzenberg: Klaus? Zábavný provokatér“. s. 2 in Právo, Zpravodajství, 5.9.2011; Rovenský, Jan.2011. „Nečas a Schwarzenberg se přebíjejí státními tajemníky“. s. 3 in Právo, Zpravodajství, 6.9.2011; Lauder, Silvie. 2011. „Výjimka z Evropy“. s. 26 in Respekt, Politika - EU a Česko, 5.9.2011; „ODS naštvala TOP 09 funkcí tajemníka pro EU. Bude smírčí řízení“ (tes). 2011. s. 2 in Mladá fronta DNES, Z domova, 1.9.2011.

19 Viz také Nečas (2007).

${ }^{20}$ Kundra, Ondřej, Spurný, Jaroslav. 2009. „Nový šéf Evropy.“ s. 15 in Respekt, Pád vlády, 30.3.2009. 
orientace). ${ }^{21}$ Také téma krize eurozóny v roce 2011 je dominantně spojováno s Václavem Klausem jako předním aktérem, je zdůrazňován jeho euroskeptický postoj a názorová opozice vůči dalším politickým osobnostem, ${ }^{22}$ a také jeho údajně významný vliv na rozhodování premiéra. $\mathrm{V}$ důsledku takto silně personalizované perspektivy médií je česká politika prezentována jako nezralá, „pubertálni““ a ve vleku „hradního stínu“ 23 jako „trucpolitika“24 a je srovnávána s jinými postkomunistickými zeměmi, v nichž podle médií politickou debatu o evropských záležitostech neovládá jediná osobnost. ${ }^{25}$ Také v silně metaforických textech $\mathrm{k}$ tématu jednání o Lisabonské smlouvě v roce 2009 vyniká síla pozice přisuzované Václavu Klausovi, prezident v obsazích vystupuje jako „krotitel s knírkem“, před jehož bičem státy Evropské unie „panáčkujî‘26, nebo jako „vrtošivý muž“, který „může podminovat nejúspěšnější mezinárodní projekt $\mathrm{v}$ dějinách lidstva“‘27, jako „salonní vyděrač“, který „vydírá Evropskou unii““ 28 zlobivý žák ${ }^{29}$ či „,bacilonosič““ roznášející „,bacil Benešových dekretư““. ${ }^{30}$ Prezident je také médii obviňován z toho, že zneužívá své pozice k prosazování svých dlouhodobých politických cílů nebo k osobním mstám. ${ }^{31}$ Média sama, ale také prostřednictvím prostoru poskytovaného Klausovým oponentům, aktualizují roli prezidenta velmi často u témat, $\mathrm{v}$ nichž nevystupuje jako hlavní aktér - vedle pádu vlády v roce 2009 také např́klad v souvislosti s diskusemi o pozici „eurotajemníka“ v roce 2011. ${ }^{32}$

Specifický př́pad personalizace, který má mezi námi sledovanými tématy zároveň nejblíže ke konceptu celebritizace politických aktérů, jsme identifikovali v př́padové studii týkající se referování o podpisu smlouvy mezi USA a Ruskem o redukci počtu jaderných zbraní (START II), ke kterému došlo v Praze v roce 2010. U této události vyniká tendence médií spojovat událost mezinárodního významu zejména s individuálními politickými reprezentanty, v tomto př́padě prezidenty Medveděvem a Obamou. Média se zaměřila především na osobní charakteristiky (,lidskost") obou státníků a na atmosféru podpisu smlouvy. Zpravodajské texty zdůrazňovaly detaily jako „Obamův široký bílý úsměv“, nervozitu obou prezidentů, levorukost prezidenta Obamy či veselou atmosféru v sále vyvolanou určitými komickými gesty státníků prí podpisu smlouvy, ${ }^{33}$ a aplikovala tak na politickou událost postupy běžné pro referování o popkulturních

\footnotetext{
${ }^{21}$ Kundra, Ondřej, Spurný, Jaroslav. 2009. „Nový šéf Evropy.“ s. 15 in Respekt, Pád vlády, 30.3.2009.; Kubáček, Jan. 2009. „Česká prezidentská republika Václava Klause.“ s. 11 in Mladá fronta DNES, Názory, 28.3.2009.

22 „Kalousek vzkázal na Hrad: Půjčku na trzích nechystám.“ (dan). 2011. s. 10 in Právo, Zpravodajství, 19.12.2011; Sedláček, Tomáš. 2011. „Veliký rozvod aneb Odcházení.“s. 11 in Hospodářské noviny, Názory - komentáře, 22.12.2011; Fischer, Petr. 2011. „Věčně nevyřešená česká otázka: Kde domov můj...?!“ s. 9 in Hospodářské noviny, Názory, 14.12.2011; Pehe, Jiří. 2011. „Přehlídka národní malosti.“ s. 6 in Právo, Publicistika, 15.12.2011.

${ }^{23}$ Koubová, Kateřina. 2011. „Blíži se chvíle, kdy Evropě opět vyznáme lásku z rozumu.“ s. 8 in Mladá fronta DNES, Názory, 13.12.2011.

${ }^{24}$ Keller, Jan. 2011. „Evropě to osladíme.“ s. 6 in Právo, Publicistika, 12.12.2011.

${ }^{25}$ Ehl, Martin. 2011. „K čemu je dobrý Brusel čili o odporu k euru a lhostejnosti k Euru.“ s. 2 in Hospodářské noviny, Př́loha - Polsko.eu, 15.12.2011; Podobně: Macháček, Jan. 2011. „Tápání po česku.“ s. 14 in Respekt, Komentáře, 12.12.2011.

${ }^{26}$ Komárek, Martin. 2009. „Klaus vyhrál, Evropa (asi) také.“s. 10 in Mladá fronta DNES, Názory, 31.10.2009.

${ }^{27}$ Komárek, Martin. 2009. „Husité to nedokázali. Porazí Evropu Klaus?“ s. 10 in Mladá fronta DNES, Názory, 14.10.2009.

${ }^{28}$ Komárek, Martin. 2009. „....ale chová se jako salonní vyděrač.“s. 8 in Mladá fronta DNES, Názory, 13.10.2009.

29 „Zlobivé Česko strhlo proti EU i dosud vzorné Slováky“ (vdo). 2009. s. 1 in Mladá fronta DNES, 19.10.2009.

${ }^{30}$ Leschtina, Jiří. 2009. „Bacilonosič Klaus.“ s. 10 in Hospodářské noviny, Názory, 19.10.2009.

${ }^{31}$ Kubáček, Jan. „Česká prezidentská republika Václava Klause.“ s. 11 in Mladá fronta DNES, Názory, 28.3.2009;

Švehla, Marek. 2009. „Co s ní.“ s. 12 in Respekt, Komentáře, 19.10.2009.

32 Königová, Marie. 2011. „Schwarzenberg: Klaus? Zábavný provokatér.“ s. 2 in Právo, Zpravodajství, 5.9.2011.

33 Gazdík, Jan. 2010. „Když i Obama s Medveděvem znervózní.“ s. 2 in Mladá fronta DNES, Summit v Česku, 9.4.2010. Podobně též: Ehl, Martin. 2010. „Nová smlouva start závodů v odzbrojení?“ s. 2 in Hospodářské noviny,
} 
nebo sportovních celebritách. Média také přejímají výraz „osobní chemie“, jímž ruský prezident Dmitrij Medveděv označil svůj osobní vztah s prezidentem Barackem Obamou, který je interpretován jako klíčový pro úspěch vyjednávání mezi zeměmi. ${ }^{34} \mathrm{~V}$ souvislosti s Obamou se aktualizuje také rámec role vnitropolitických zájmů konkrétního politika $\mathrm{v}$ mezinárodních otázkách - autoři interpretují podpis smlouvy START II jako strategii prezidenta Spojených států, jak posílit svoji pozici v USA. ${ }^{35}$ Mediální pokrytí události je nápadné konvergencí mediálních obsahů (média se zaměřují na stejné detaily, rámcování události jako klíčové pro Českou republiku je velmi blízké např́rc sledovanými tištěnými médii) a právě ve zdůrazňování detailů irelevantních pro výkon politické funkce (levorukost Obamy) hraničí s privatizací (van Aelst et al. 2012) nebo celebritizací (Frantová 2010: 2) ${ }^{36}$ Hraniční tendence mezi individualizací a privatizací (van Aelst et al. 2012) je patrná také v mediálních textech, které se zaměřují právě na status celebrit obou prezidentů - zdůrazňují potřebu českých politiků vyfotografovat se s prezidenty Obamou a Medveděvem (což jim nebylo umožněno, přestože „někteří by to zvláště před volbami uvítali“) $)^{37}$ nebo zveřejňují „výsledky soutěže“ českých politiků o četnost kontaktů s prezidentem Obamou, v níž premiér Jan Fischer Obamovi „rukou potřese víckrát než ostatní“.38

\section{5.b Lokální spory v globálním kontextu: domestikace zahraničních událostí}

Perspektiva lokálních sporů jednotlivých politiků či politických stran je velmi častou mediální strategií při informování o zahraničně-politických událostech. Častá je také nápadná snaha přiblížit mezinárodně významné události domácím publikům specifickým rámcováním s důrazem na historii či význam České republiky (viz níže). I když tyto tendence zřejmě souvisejí s významem zpravodajské hodnoty (kulturnî) blízkosti (Galtung a Ruge 1965) a výše je popisujeme v souvislosti s konfliktností až polarizací personalizovaného politického diskurzu v médiích, př́znakovost takového rámcování a jeho samoúčelnost nabývají dlouhodobě takové intenzity, že je nazýváme domestikací zahraničně-politických událostí v českých médiích. Domestikace má tedy dvě klíčové podoby: a) explicitní „přibližování“ tématu prostřednictvím paralel s událostmi $\mathrm{v}$ národní historii nebo $\mathrm{v}$ historii zemí kulturně blízkých; b) zdůrazňování lokálních aspektů tématu globálního, zejména vztahování mezinárodních událostí k vnitrostátní, př́p. vnitrostranické politice (aniž by tato přímo s mezinárodním významem události souvisela), a také zvýznamňování role České republiky v události.

Strategie tohoto umělého vytváření či disproporčního vyzdvihování zpravodajské hodnoty blízkosti se v kontextu zahraničně-politického zpravodajství a publicistiky v českém tisku úzce

\footnotetext{
Téma, 9.4.2010; Kaiserová, Zuzana a Teodor Marjanovič. 2010. „Smlouva o odzbrojení a námluvy Obamy s Medveděvem.“"s. 1 in Mladá fronta DNES, Titulní strana, 9.4.2010.

${ }^{34}$ Kaiserová, Zuzana a Teodor Marjanovič. 2010. „Smlouva o odzbrojení a námluvy Obamy s Medveděvem.“ s. 1 in Mladá fronta DNES, Titulní strana, 9.4.2010. Též: Anýž, Daniel. 2010. „START II, historická dohoda podepsána.“ s. 1 in Hospodářské noviny, 9.4.2010. Podobně také: Černý, Adam. 2010. „Jsme ti, kteří to udělali“. s. 4 in Hospodářské noviny, Téma, 9.4.2010; Černý, Adam. 2010. „Jsme ti, kteř́ to udělali“. s. 4 in Hospodářské noviny, Téma, 9.4.2010.

35 Anýž, Daniel. 2010. „Obamův triumf: Senát ratifikuje START II.“ s. 7 in Hospodářské noviny, Svět, 22.12.2010. Podobně též: Marjanovič, Teodor. 2010. „Obamova bitva o Nový START.“ s. 6 in Mladá fronta DNES, Ze světa, 23.12.2010; Soukup, Ondřej. 2010. „Moskva varuje před závody ve zbrojení.“ s. 7 in Hospodářské noviny, Svět, 2.12.2010.

36 Viz poznámka pod čarou č. 3.

${ }^{37}$ Pokorný, Jakub. 2010. „Šéfové stran se s prezidenty nevyfotí, uvidí je jen u oběda.“ s. 4 in Mladá fronta DNES, Summit v Česku, 8.4.2010.

${ }^{38}$ Kreč, Luboš a Zuzana Keményová. 2010. „Fischer uvidí Obamu čtyřikrát. Lépe na tom bude jen bodyguard.“ s. 4 in Hospodářské noviny, Téma, 7.4.2010.
} 
váže na výše popsané tendence personalizovat politiku a zdůrazňovat její negativní aspekty. Naplno tendence k domestikaci vyniká u tématu podpisu smlouvy START II prezidenty Obamou a Medveděvem v Praze v roce 2010. Přestože některé texty se pozastavují nad provinčností takového rámcování, ${ }^{39}$ případně upozorňují na omezený vliv české strany na celou událost, ${ }^{40}$ téma je dominantně vztaženo k České republice, její prestiži a vnitropolitické situaci. „České“ rámce podpisu smlouvy se týkají otázek neutrality země, vnitropolitického soupeření, významu události pro českou politiku (či lépe řečeno pro jednotlivé politiky), a také prestiže České republiky. Právě texty odkazující ke kráse pražské architektury ${ }^{41}$ či litující toho, že smlouva nebude označována jako „Pražská‘ ${ }^{\text {‘42 }}$, jsou nápadné zdůrazňováním symbolického rozměru politických událostí a umělým vytvářením významu České republiky v mezinárodních otázkách. Vnitropolitický kontext podpisu dohody je dalším z výrazných rámců, který zdůrazňuje prínos události pro prezidenta Václava Klause, ${ }^{43}$ předvolební zájmy představitelů politických $\operatorname{stran}^{44}$ nebo vnitropolitické konflikty v souvislosti s hradním protokolem. ${ }^{45}$

Jako domestikaci zahraničně-politických témat vnímáme také dlouhodobý trend tištěných médií přibližovat tyto události většinou poněkud násilným vytvářením paralel s událostmi národní historie českých zemí nebo zemí kulturně blízkých - tendence vyhledávat historické paralely v českém kontextu je patrná u většiny sledovaných témat ve všech analyzovaných letech, proto se jí níže věnujeme samostatně.

\section{5.c Bipolární rozdělení světa a ruská hrozba}

Bipolární rozdělení světa, specifická pozice Ruska (jeho určitá nezařaditelnost do schématu přítel vs. hrozba) a Česká republika jako země závislá na silném protektorovi jsou dlouhodobě silnými rámci vyskytujícími se v zahraničně-politickém zpravodajství a publicistice sledovaných tištěných médií. Tento trend odpovídá převládající polarizaci politického diskurzu a aktualizuje klasický narativ světa rozděleného na sféry vlivu Spojených států amerických a Svazu sovětských socialistických republik (novodobě Ruska) v době studené války. Pozice České republiky je tak v logice tohoto narativu prezentována jako pozice závislé země, která se musí rozhodnout, ke které části světa chce a bude patřit.

\footnotetext{
39 Vodička, Milan. 2010. „Summit znamená pět minut slávy. Nic víc.“ s. 12 in Mladá fronta DNES, Názory, 25.3.2010.

40 „Do protokolu Hrad nemohl skoro mluvit،“ (jam, jas). 2010. s. 5 in Hospodářské novin, Téma, 9.4.2010.

Podobně také: Gazdík, Jan. 2010. „Když i Obama s Medveděvem znervózní.“ s. 2 in Mladá fronta DNES, Summit v Česku, 9.4.2010.

${ }^{41}$ Gazdík, Jan. 2010. „Když i Obama s Medveděvem znervózní.“ s. 2 in Mladá fronta DNES, Summit v Česku, 9.4.2010.

42 Marjanovič, Teodor. 2010. „24 hodin středem světa.“ s. 1 in Mladá fronta DNES, Titulní strana, 8.4.2010.

Podobně také: Sobota, Jiř́. 2010. „A co my?“ s. 15 in Respekt, Komentáře, 12.4.2010.

${ }^{43}$ Kaiserová, Zuzana. 2010. „Obama, Medveděv a Klaus. Český prezident povyrostl.“ s. 4 in Mladá fronta DNES, Summit v Česku, 9.4.2010. Podobně také: Gazdík, Jan. 2010. „Když i Obama s Medveděvem znervózní.“ s. 2 in Mladá fronta DNES, Summit v Česku, 9.4.2010; Anýž, Daniel. 2010. „START II, historická dohoda podepsána.“ s. 1 in Hospodářské noviny, Titulní strana, 9.4.2010.

44 Pokorný, Jakub. 2010. „Šéfové stran se s prezidenty nevyfotí, uvidí je jen u oběda.“ s. 4 in Mladá fronta DNES, Summit v Česku, 8.4.2010.

45 ,Jestli totiž protokol k něčemu nemá sloužit, pak k vyřizování politických účtů. Právě to ale zjevně udělali na Hradě, když na podpis smlouvy START II a následný oběd s prezidenty Obamou a Medveděvem pozvali zástupce všech parlamentních stran - s výjimkou zelených.“ („Respekt.“ s. 6 in Respekt, Anketa, 12.4.2010) Podobně též: „Včerejší den minuta po minutě.“ s. 2 in Mladá fronta DNES, Summit v česku, 9.4.2010.
} 
Nejasnost ohledně zařazení Ruska ve schématu „spojenec vs. hrozba“ je patrná v souvislosti s podpisem dohody START II v Praze v roce 2010. Situace, kdy Rusko a Spojené státy uzavírají symbolicky významnou smlouvu, narušuje zažité studenoválečné schéma, s nímž média běžně pracuji ${ }^{46}$. Autoři proto vyjadřují obavy o zájem Spojených států o středoevropský region ${ }^{47} \mathrm{a}$ konstruují obraz Ruska coby nezařaditelné země, která sice není př́ímou jadernou hrozbou jako Írán nebo KLDR, ${ }^{48}$ zároveň jí ale také není možné důvěřovat. ${ }^{49}$ Texty akcentují nejednoznačné vyznění významu podpisu smlouvy START II pro Českou republiku a rámcují téma skrze možné ohrožení středoevropského regionu Ruskem, at' už částečným popíráním takové hrozby, ${ }^{50}$ uklidňováním těch, kteří se jí obávaji1, ${ }^{51}$ nebo jejím zdůrazňováním. ${ }^{52}$ Některé texty neurčitý strach z Ruska konkretizují jako obavy z neutrality České republiky (coby země hostící dvě světové mocnosti), která může představovat problém pro českou diplomacii. ${ }^{53}$ Další explicitní hrozbou konstruovanou médii jsou ekonomické zájmy Ruska vČeské republice, skrze něž může uplatňovat svi̊j vliv, zejména v souvislosti se zakázkou na dostavbu temelínské atomové elektrárny. ${ }^{54}$ Rámec ekonomického vlivu Ruska je př́itomný také u tématu protiraketové obrany v roce 2009 (věnujeme se mu níže) a krize eurozóny v roce 2011, kdy je o Rusku uvažováno jako o jediné možné alternativě $\mathrm{k}$ Evropské unii, pokud se jedná o hospodářskou politiku ČR. Takový argument nastolují jak samotní političtí zástupci, tak mediální komentátoři. ${ }^{55}$

Silně polarizovaný diskurz pracující s narativem bipolárního rozdělení světa a závislé pozice satelitů dvou největších mocností je typický také pro mediální rámcování situace, $\mathrm{v}$ níž prezident Spojených států amerických oficiálně oznámil reprezentaci České republiky rozhodnutí USA neuskutečnit výstavbu protiraketové základny v České republice. Aktéŕi jsou členěni na základě dichotomie my vs. oni, přičemž „my“ zahrnuje v nejširším smyslu Českou republiku jako součást Evropy, úžeji ale také samostatně nebo spolu s Polskem. Do kategorie „oni“ spadají Spojené státy a Rusko, výjimečně také Německo a v historizujících paralelách Francie a Anglie. Podobně jako v př́padě podpisu START II je nastolována (politiky i médii samotnými) hrozba Ruska poté, co Spojené státy, resp. personalizovaně prezident Obama „dal přednost domácím problémům a nové vstríícnosti vưči Rusku před zajištěním bezpečnosti Evropy a euroatlantickou vazbou, která je klíčová pro svobodu starého kontinentu“ “. ${ }^{56}$ Ruská hrozba je prezentována jako prímý důsledek rozhodnutí Spojených států, texty zmiňují zradu spojence (USA), „,na kterého jsme spoléhali“ a

\footnotetext{
46 Anýž, Daniel. 2010. „START II, historická dohoda podepsána.“ s. 1 in Hospodářské noviny, Titulní strana, 9.4.2010.

47 Anýž, Daniel. 2010. „Obamova jaderná gorila a Česko““ s. 8 in Hospodářské noviny, Názory, 22.11.2010.

48 Anýž, Daniel. 2010. „Útok KLDR, špatná zpráva pro Obamu.“ s. 7 in Hospodářské noviny, Svět, 25.11.2010.

${ }^{49}$ Soukup, Ondřej. 2010. „Moskva varuje před závody ve zbrojení،“ s. 7 in Hospodářské noviny, Svět, 2.12.2010.

Podobně také: Anýž, Daniel. 2010. „Obamův triumf: Senát ratifikuje START II.“ s. 7 in Hospodářské noviny, Svět, 22.12.2010; Marjanovič, Teodor. 2010. „Obamova bitva o Nový START.“ s. 6 in Mladá fronta DNES, Ze světa, 23.12.2010.

50 Sobota, Jiř́i. 2010. „A co my?“ s. 15 in Respekt, Komentáře, 12.4.2010.

${ }^{51}$ Ehl, Martin. 2010. „Obama v Praze uklidňoval spojence.“ s. 7 in Hospodářské noviny, Svět, 9.4.2010. Podobně také: Sobota, Jiř́i. 2010. „A co my?“ s. 15 in Respekt, Komentáře, 12.4.2010.

52 Ehl, Martin. 2010. „Obama v Praze uklidňoval spojence.“ s. 7 in Hospodářské noviny, Svět, 9.4.2010.

${ }^{53}$ „Obama a Medveděv potvrdili schůzku v Praze.“s. 5 in Hospodářské noviny, Česko, 25.3.2010.

${ }^{54}$ Kaiserová, Zuzana, Klímová, Jana. 2010. „Obama: Dostavíme vám Temelín.“ s. 1 in Mladá fronta DNES, Titulní strana, 10.4.2010; Marjanovič, Teodor. 2010. „24 hodin středem světa.“ s. 1 in Mladá fronta DNES, Titulní strana, 8.4.2010; Sobota, Jiř́i. 2010. „A co my?“ s. 15 in Respekt, Komentáře, 12.4.2010.

55 Mitrofanov, Alexandr. 2011. „Plížením vzad.“ s. 6 in Právo, Publicistika, 14.12.2011. Podobně též zde od téhož autora: Mitrofanov, Alexandr. 2011. „Volba.“ s. 6 in Právo, Publicistika, 12.12.2011.

56 Topolánek, Mirek. 2009. „Nenechme USA obrátit se zády.“s. 10 in Hospodářské noviny, Názory, 18.9.2009.
} 
který nás „vyměnil za vlastní lepší vztahy s Ruskem, z nějž my máme oprávněný strach“,57 „hodil Česko a Polsko přes palubu“.$^{58}$ Význam události je zdůrazňován slovním spojením „doba poradarová‘ ${ }^{\text {‘59 }}$ odkazujícím k epochální změně a aktualizacemi historických hrozeb jak v politické, tak ekonomické podobě. ${ }^{60}$ Rámec ruské hrozby a studenoválečného rozdělení světa udržují v mediální agendě i texty, které kritizují submisivní, nedůstojné a provinční reakce na vzniklou situaci, ${ }^{61}$ „černobílé vidění s dvěma póly - odporným ruským medvědem a hodným americkým slonem“ "62 vyzývají ke stabilizaci politické situace, ${ }^{63}$ „upevnění našeho ústavního a právního řádu“

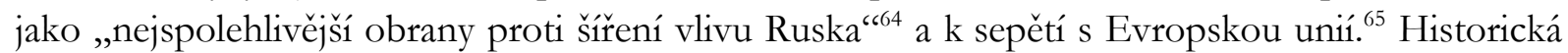
traumata země aktualizují rámce odkazující k protektorátu ${ }^{66}$ nebo závislosti na „mocném dubisku“. ${ }^{67}$

\section{5.d Zvony zrady: historická traumata a metafory $v$ českém tisku}

Zejména názorová publicistika sledovaných tištěných médií je ve všech analyzovaných letech nápadná tím, že komentuje události zahraniční politiky výrazně schematicky a využívá emotivního apelu prostřednictvím metafor, př́měrů a aktualizace historických traumat země nebo regionu. Formální podoba textů tak akcentuje polarizaci debaty a publicistické texty nabízejí pohled zjednodušující problematiku i postoje a charakteristiky aktérů do snadno pochopitelných schémat. Velmi častým rámcem v komentáŕích $\mathrm{k}$ jednotlivým zahraničně-politickým událostem je aktualizace hrozeb prostřednictvím významných momentů národní historie. Historická traumata českých zemí, symbolizovaná vždy konkrétním rokem, nebo jiná, z politického hlediska významná období (nap̌̌r. rok 1989) se v názorových textech objevují nejčastěji jako připomínka ohrožení zahraničními nepřáteli (Rusko, Německo) nebo vnitřním nepř́telem (levice). Média tyto paralely sama nastolují, př́padně je přejímají od politických aktérů. ${ }^{68} \mathrm{~V}$ souvislosti s pádem vlády v době předsednictví ČR v EU v roce 2009 tak média aktualizovala traumata vpádu zahraničních vojsk z let 1938 a $1968^{69}$ nebo politického převratu roku $1948^{70}$ a následné atmosféry začátku padesátých let: „Atmosféra je ostrá, zlá, připomíná začátek padesátých let [...] Je to atmosféra

\footnotetext{
57 Šimůnek, Petr. 2009. „44 slov.“ s. 1 in Hospodářské noviny, 18.9.2009.

58 Steigerwald, Karel. 2009. „Nikdo nás nezradil. My chceme nesvobodu.“ s. 10 in Mladá fronta DNES, Názory, 22.9.2009.

59 Pšenička, Jiří. 2009. „Plíživý návrat před rok 1989.“ s. 32 in Ekonom, Politika a byznys, 24.9.2009.

${ }^{60}$ Hanák, Jiří. 2009. „Házená،“ s. 6 in Právo, Publicistika, 18.9.2009; Rychetník, Luděk. 2009. „Zrada, nebo výzva k dospělosti?“ s. 10 in Hospodářské noviny, Názory, 29.9.2009; Zlámalová, Lenka. 2009. „Mezi radarem a

Moskvou.“ s. 10 in Hospodářské noviny, Názory, 18.9.2009; Buchert, Viliam. 2009. „Obamovo mnichovanství a 'vítězství" českého lidu."s. 12 in Mladá fronta DNES, Názory, 18.9.2009.

${ }^{61}$ Hanák, Jiří. 2009. „Hloupé a nedůstojné.“ s. 6 in Právo, Publicistika, 22.9.2009.

62 Mitrofanov, Alexandr. 2009. „Rekviem za radar.“s. 6 in Právo, Publicistika, 18.9.2009.

63 Suchý, Petr. 2009. „Jak dál po konci brdského radaru.“ s. 12 in Hospodářské noviny, Názory, 22.9.2009. Mocek, Michal. 2009. „Žádná prohra - jen nová výzva pro Čechy a Poláky.“ s. 6 in Právo, Publicistika, 19.9.2009.

${ }^{64}$ Rychetník, Luděk. 2009. „Zrada, nebo výzva k dospělosti?““ s. 10 in Hospodářské noviny, Názory, 29.9.2009.

${ }^{65}$ Dienstbier, Jiř́. 2009. „Americká lekce naivním Čechům.“ s. 6 in Právo, Publicistika, 22.9.2009.

66 „Je skličující představou, že vyžilý kontinent potřebuje nějakého ,protektora‘, aby vůbec mohl fungovat. Kde protektor, tam protektorát.“ (Komárek, Stanislav. 2009. „Zlomené dvacetiletí.“ s. 13 in Hospodářské noviny, Názory, 23.9.2009.)

${ }^{67}$ Dienstbier, Jiř́. 2009. „Americká lekce naivním Čechům.“ s. 6 in Právo, Publicistika, 22.9.2009.

68 Topolánek, Mirek. 2009. „Nenechme USA obrátit se zády.“ s. 10 in Hospodářské noviny, Názory, 18.9.2009.

69 „Co je nového.“ s. 1 in Hospodářské noviny, 30.3.2009.

${ }^{70}$ Steigerwald, Karel. 2009. „Kdo včera vyhrál? Komunisté.“ s. 9 in Mladá fronta DNES, Názory, 25.3.2009.
} 
února 1948, levice jde k moci, pravice dělá vše, aby se to povedlo.“71 Tentýž autor čerpá také z historicky mnohem vzdálenějšího období a přirovnává českou politiku dokonce $\mathrm{k}$ době husitské. $^{72}$ Další událost roku 2009, rozhodnutí Spojených států amerických odstoupit od výstavby protiraketové obrany v původní podobě („radaru“) vČeské republice, vyvolalo v mediálních obsazích velmi emotivní reakce vyjadřované opět zejména prostřednictvím paralel s historickými křivdami a „zradami“. Zjevné je rámcování události prostřednictvím zrady prezidenta Obamy personalizujícího Spojené státy $^{73}$, dojem zrady osudového významu je umocněn také př́měry $\mathrm{k}$ mnichovskému traumatu - $\mathrm{v}$ mediální agendě se uplatňuje a je $\mathrm{v}$ ní udržován obraz národa opuštěného spojenci, mimo jiné explicitním odkazem na dobově aktuální básnickou reakci na „mnichovskou zradu“:

\begin{abstract}
„Zvoní zvoní zrady zvon, čí ruce ho rozhoupaly, Francie sladká, hrdý Albion a my jsme je milovali. Tak popsal František Halas ve sbírce Torzo naděje v roce 1938 mnichovanství spojenců, které přispělo k zániku meziválečného Československa. Mnichovanství u některých spojenců přežívá i dnes. Bohužel na rozdíl od „Halasova“ roku 1938 se k němu přidává $i$ většina české veřejnosti.“"74
\end{abstract}

Výhrůžnou paralelu s podpisem mnichovské dohody v roce 1938 média aktualizovala také v souvislosti s tématem podpisu Lisabonské smlouvy, ${ }^{75}$ další texty $\mathrm{k}$ tématu se zaměřily na hrozby vyplývající z odmítání evropské integrace, ironicky varovaly před budováním nové opony, „která nás ochrání před nájezdy sudetských Němců“, a hrozily „prezidentskou diktaturou“ Václava Klause a Jiř́ho Paroubka či rozebráním české ekonomiky Rusy. ${ }^{76}$ Téma Mnichova 1938 vstoupilo do mediální agendy také $\mathrm{v}$ roce 2011 v souvislosti s krizí eurozóny, tentokrát v téměr okultní spekulaci o podobnosti úmrtí prezidentů Tomáše Garrigua Masaryka a Václava Havla:

„Historie nabízí podivuhodné paralely: rok po smrti Masaryka přišla mnichovská krize, pak okupace a válka... Každého napadne: současná situace, zvlášt’ v Evropě také nevypadá zrovna nejlépe, zažíváme další vlnu ekonomické krize; nemáme se bát budoucnosti? Nebo jinak: Není Havlova smrt předzvěstí špatných časů, jako byla smrt Masarykova?‘77

Konstruování historických paralel se $\mathrm{v}$ tomto roce neomezilo pouze na události prrímo spojené s Českou republikou. Dění v arabském světě během tzv. arabského jara v roce 2011 se média snažila přibližit konstruováním paralel s událostmi z evropské, resp. přímo české historie, přestože zároveň dávala velký prostor hlasům (i politickým), ${ }^{78}$ podle nichž Evropa a Západ

\footnotetext{
${ }^{71}$ Steigerwald, Karel. 2009. „Nenávist, matka politiky české““ s. 8 in Mladá fronta DNES, Názory, 24.3.2009.

72 Ibid.

73 Marjanovič, Teodor. 2009. „Obrátit se k vám zády? To nikdy, sliboval.“s. 12 in Mladá fronta DNES, Názory, 18.9.2009.

${ }^{74}$ Buchert, Viliam. 2009. „Obamovo mnichovanství a 'vítězství českého lidu. s. 12 in Mladá fronta DNES, Názory, 18.9.2009. Podobně také Kohout, Pavel. 2009. „Hazard se svobodou znamená sebevražedné riziko.“ s. 11 in Mladá fronta DNES, Názory, 26.9.2009.

75 „Vstoupí-li Lisabon v platnost, nenastane evropský ráj na zemi, ale naopak tvrdý boj o pozice. [...] Abychom zase jednou nemuseli svádět vinu na druhé a básníci nepsali opět díla o tom, jak ,zvoní zrady zvon‘.“ (Schnur, Petr. 2009. „Lisabon a ,sudetoněmecké‘ téma. s. 6 in Právo, Publicistika, 26.10.2009)

${ }^{76}$ Macháček, Jan. 2009. „Varianta Rusko soft.“ s. 34 in Respekt, Ekonomika, 19.10.2009.

${ }^{77}$ Navara, Luděk. 2011. „Masaryk a Havel, mocnáři ducha.“ s. 5 in Mladá fronta DNES, Václav Havel, 22.12.2011.

78 Anýž, Daniel. 2011. „Vzkazuji do Libye: Éto váše d'élo.“ s. 11 in Hospodářské noviny, Názory, 23.3.2011.
} 
obecně situaci v arabských zemích př́liš nerozumí (a to ani na úrovni expertů - analytiků, úředníků, špionů). ${ }^{79} \mathrm{~V}$ mediálních obsazích tak „arabské jaro“ bylo přirovnáváno k evropskému „jaru národů“ v roce $1848^{80}$, revolučnímu roku 1989, roku 1956 v Budapešti nebo 1968 v Praze, ${ }^{81}$ podle některých autorů „míra změn [po ,velkém třesku v arabském světě - pozn. aut.] bude

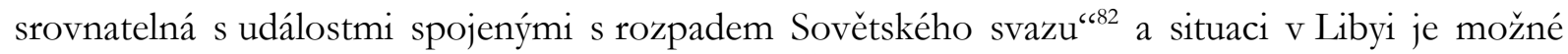
srovnávat s občanskými válkami v Jugoslávii a ve Španělsku. ${ }^{83}$

Vedle zmíněných historických paralel, s nimiž média často velmi emotivně propojují aktuální události, přispívá $\mathrm{k}$ emocionalizaci zahraničně-politického diskurzu v médiích také metaforičnost vyjadřování a labelling. Obliba příměrů, a to výrazně i mimo názorové texty, je nápadná vobsazích vztahujících se ke krizi eurozóny v roce 2011. Typická je pro ně silná autostereotypizace ve smyslu stereotypů vztahujících se $\mathrm{k}$,vlastnostem českého národa“. Metaforičnosti diskurzu je dosahováno prostřednictvím časté personalizace států Evropské unie jako partnerů v manželství, které se nachází v krizi; ${ }^{84}$ některé texty tuto metaforu rozpracovávají do detailů, objevuje se i odkaz k populární kultuře - k filmu Válka Roseových ${ }^{85}$-, média konstruují představu o sňatku z rozumu, do něhož Česká republika s Evropskou unií vstoupila. ${ }^{86}$ Podobně euroskeptické texty přirovnávají systém půjček MMF k „charitativnímu socialismu“, euro k Titaniku a EU k „,nenasytné stvưře“, jejíž krmení je třeba zastavit, „než ze všech svých zemí vysaje poslední šesták, poslední kapku krve a poslední elektron tvưrčí energie“، ${ }^{87}$ Texty, jejichž volbou je rámec národních autostereotypů, zdůrazňují „české zápecnictví” nebo sklon k izolacionismu a opět pracují s obraznými vyjádřeními. ${ }^{88}$ Národní stereotyp švejkovství aktualizuje text, který pasivitu ČR v jednáních o připojení se k fiskální unii oslavuje (i když poněkud ironicky) jako vzor pro ostatní země. ${ }^{89}$ Vedle autostereotypizace přjejímají média také labelling ${ }^{90}$ pocházející z „bruselských kuloárư“ a referují o tom, že v Bruselu „dostala už nová skupinka eurooutsiderů své jméno: ř́ká se jim CHUKS (Čakové)““. ${ }^{91}$ Média prejejímají tento faul v politickém diskurzu jako nálepku, transformují ho do českého tvaru a spojují ho s negativními

\footnotetext{
${ }^{79}$ Musil, Michal. 2011. „Ohromné arabské selhání rozumbradů, analytiků a věštců.“s. 10 in Mladá fronta Dnes, Názory, 1.3.2011.

${ }^{80}$ Koubová, Kateřina, Novotný, Pavel. 2011. „Libyi rozumí jiní, my se zase vyznáme v Izraeli.“ s. 8 in Mladá fronta DNES, Ze světa, 22.4.2011.

81 Glucksmann, André. 2011. „Konečně!“ s. 78 in Respekt, 4.4.2011.

82 Švehla, Marek. 2011. „Naše arabská podívaná.“s. 14 in Respekt, Komentáře, 4.4.2011.

${ }^{83}$ Heger, Lubomír. 2011. „Bezletová sezona.“ s. 12 in Mladá fronta Dnes, Názory, 21.3.2011.

${ }^{84}$ Sedláček, Tomáš. 2011. „Veliký rozvod aneb Odcházení.“s. 11 in Hospodářské noviny, Názory - komentáře, 22.12.2011.

${ }^{85}$ Hrstková, Julie. 2011. „Proč platit jídlo na cizím talíríi.“s. 8 in Hospodářské noviny, Názory, 14.12.2011.

${ }^{86}$ Koubová, Kateřina. 2011. „Blíží se chvíle, kdy Evropě opět vyznáme lásku z rozumu.“ s. 8 in Mladá fronta DNES, Názory, 13.12.2011. Podobně také zde: Sobota, Jiř́, Šafaříková, Kateřina. 2011. „Evropský rozvod.“ s. 17 in Respekt, Politika - ekonomika, 12.12.2011.

${ }^{87}$ Kuras, Benjamin. 2011. „Krmení nenasytné stvůry.“ s. 12 in Mladá fronta DNES, Názory, 21.12.2011.

88 Sedláček, Tomáš. 2011. „Nehas, co tě pálí aneb Čechomýty.“ s. 9 in Hospodářské noviny, Názory, 15.12.2011.

Z obsahového hlediska podobně také: Uhl, Petr. 2011. „Spojenectví sobectví a svévole.“ s. 6 in Právo, Publicistika, 15.12.2011.

${ }^{89}$ Šnídl, Vladimír. 2011. „České ,švejkovství na summitu inspirovalo.“ s. 44 in Ekonom, Téma - budoucnost EU, 15.12.2011.

${ }^{90}$ K mediálnímu labellingu viz např. Haller a Bruce-Rahn (2006) nebo Steuter (1990).

91 „'Tady v Bruselu dostala už nová skupinka eurooutsiderů své jméno: říká se jim CHUKS (Čakové), ' [...] Zkratka vznikla z počátečních písmen čtveřice zemí - Česka, Mad’arska (Hungary), Británie (United Kingdom) a Švédska které na summitu odmítly podepsat první návrh změn.” „Zástupcům váhajících států včetně Česka se říká Čakové.“ (sti). 2011. s. 3 in Mladá fronta DNES, Záchrana eura, 10.12.2011.
} 
konotacemi prostřednictvím označení jako „eurooutsideři“‘. Výrazně emotivní a naplněné příměry jsou také texty týkající se situace, v níž prezident Václav Klaus v roce 2009 oddaloval podpis Lisabonské smlouvy po jejím odsouhlasení oběma komorami Parlamentu ČR, ${ }^{92}$ nebo jmenování „dvou eurotajemníkü“ v roce 2011.

\section{Závěr}

Výsledky analýz zaměřených na mediální referování o zahraničně-politických událostech, které souhrnně prezentujeme $\mathrm{v}$ tomto článku, korespondují se závěry, podle nichž politická komunikace $\mathrm{v}$ médiích tenduje k odklonu od zaměření se na systémy a procesy rozhodování směrem k zájmu o individuální politické aktéry (Karvonen 2010; Mazzoleni 2000; McAllister 2007; Swanson a Mancini 1996). Česká zahraniční politika je v obsazích sledovaných médií prezentována optikou sporů jednotlivců či politických stran, silná polarizace a užívání metaforického jazyka a negativity či konfliktnosti podporují emotivní vyznění textů. $\mathrm{V}$ informování o zahraničně-politických událostech jsme identifikovali zajímavou tendenci, kterou označujeme jako snahu o domestikaci zahraničních událostí. Ačkoli pravděpodobně souvisí s mediálním důrazem na zpravodajskou hodnotu blízkosti, nápadná je tato perspektiva samoúčelnou snahou přibližit mezinárodně významné události domácím publikům specifickým rámcováním s důrazem na historii (paralely s historickými událostmi v českých zemích) či význam České republiky a na lokální spory jednotlivých politiků či politických stran. Dlouhodobě silnými rámci vyskytujícími se v zahraničně-politickém zpravodajství a publicistice sledovaných tištěných médií jsou také bipolární rozdělení světa a s ním související specifická pozice Ruska (jeho určitá nezařaditelnost do schématu „přítel vs. hrozba“) a pozice České republiky jako země závislé na silném protektorovi.

Za zajímavý považujeme také pozorovaný rozpor mezi celkovou emocionalizací politického diskurzu $\mathrm{v}$ médiích (odklon od argumentů, príklon $\mathrm{k}$ metaforám, historickým paralelám, hrozbám, hádkám atp.) a mediálním lpěním na nutnosti expertního rozhodování v určitých otázkách. Média expertízu často explicitně preferují před politickým rozhodováním, které označují za populistické, př́liš zohledňující „hlas ulice“, a politický diskurz explicitně prezentují jako odtažitý od odborného rozhodování (Nečas 2009; Nečas a Vochocová 2010,2011; Vochocová a Nečas 2012). Navzdory silné tendenci k rozvolňování přísně racionálního, deliberativního politického diskurzu tak média ve svých obsazích nezrrídka preferují jeden konkrétní pohled na správu věcí veřejných, který je v literatuře reflektován jako ze své podstaty exkluzivní (ve smyslu vylučování různorodých hlasů, zejména těch identifikovaných jako neodborné - Marx Ferree et al. 2002).

Závěry, které prezentujeme výše, je nutné číst s ohledem na limity vyplývající z našeho předmětu zájmu, jímž jsou pouze mediální obsahy. Jedná se tedy o pokus popsat stav a převažující tendence $\mathrm{v}$ mediální konstrukci zahraničně-politických událostí na základě několika př́padových studií realizovaných během čtyř let. Usilujeme o pojmenování zahraničněpolitického diskurzu ve sledovaných mediálních obsazích, ale naším cílem v žádném případě není hodnotit úroveň zpravodajství v kontextu normativních teorií. V tomto smyslu je inspirativní sledovat ojedinělé tendence médií k určité sebereflexi - texty, které zaujímají ve vztahu

\footnotetext{
92 Komárek, Martin. 2009. „Husité to nedokázali. Porazí Evropu Klaus?“ s. 10 in Mladá fronta DNES, Názory, 14.10.2009; Komárek, Martin. 2009. „Klaus vyhrál, Evropa (asi) také.“ s. 10 in Mladá fronta DNES, Názory, 31.10.2009; Steigerwald, Karel. 2009. „Odborník v metání kozelců.“ s. 10 in Mladá fronta DNES, Názory, 2.11.2009; Leschtina, Jiř́. 2009. „Bacilonosič Klaus.“ s. 10 in Hospodářské noviny, Názory, 19.10.2009.
} 
k jednotlivým námi sledovaným tématům metamediální perspektivu, vysvětlují roli médií v politické komunikaci a kritizují převažující podobu politické debaty v médiích. Přesto ale paradoxně samy bud' posilují nastolenou agendu (reprodukcí nastolených rámců, i když z kritického pohledu), nebo rozvijejí některý z trendů, které popisujeme výše - reprodukují národní autostereotypy, ${ }^{93}$ schematizují prostřednictvím odkazů $\mathrm{k}$ historickým paralelám a hrozbám silně polarizovaných politických postojü ${ }^{94}$ nebo dále rozvíjejí odmítanou metaforičnost. ${ }^{95}$ Tím tyto jevy udržují v mediální agendě, určitým způsobem je legitimizují, a podílejí se tak spolu s ostatními texty, které kritizují, na nápadné entertainizaci politického diskurzu v médiích.

\section{Seznam literatury}

Berger, Peter a Thomas Luckmann (1999): Sociální konstrukce reality. Brno: Centrum pro studium demokracie a kultury.

Blumler, Jay a Dennis Kavanagh (1999): „The third age of political communication: Influences and features." Political Communication 16, s. 209-230.

Cohen, Bernard (1965): The Press and foreign policy. Berkeley: Univ. of California.

Crossley, Nick a John Roberts (2004): After Habermas: New Perspectives on the Public Sphere. WileyBlackwell.

Entman, Robert (2004): Projections of Power: Framing News, Public Opinion, and U.S. Foreign Policy. Chicago and London: The University of Chicago Press.

Frantová, Veronika (2010): „The Celebritization of Politicians. Paper for Europaeum Summer School 2010 - Bologna“" on-line: http://www.europaeum.org/files/teaching/summerschools/SS2010_Veronika-Frantova-paper.pdf) [ověřeno k 6. 8. 2006]

Funkhouser, Ray (1973): „The issues of the sixties: An exploratory study in the dynamics of public opinion." Public Opinion Quarterly 37(1), s. 62-75. DOI: 10.1086/268060

Galtung, Johan a Ruge, Mari (1965): „The Structure of Foreign News: The Presentation of the Congo, Cuba and Cyprus Crises in Four Norwegian Newspapers. "Journal of Peace Research 2(1), s. 64-90. DOI: $10.1177 / 002234336500200104$

Gerbner, George (2002): „Growing up with television: cultivation processes.“ In Jennings Bryant a Dolf Zillman (eds.) Media Effects: Advances in Theory and Research. Routledge, s. 43-67

Goffman, Erving (1963): Behavior in Public Places: Notes on the Social Organization of Gatherings. New York: The Free Press.

Habermas, Jürgen (2000): Strukturální přeměna veřejnosti. Praha: Filosofia, nakladatelství Filosofického ústavu AV Čr.

Habermas, Jürgen (2006): „Political Communication in Media Society: Does Democracy Still Enjoy an Epistemic Dimension? The Impact of Normative Theory on Empirical Research." Communication Theory 16(4), s. 411-426. DOI: 10.1111/j.1468-2885.2006.00280.x

\footnotetext{
93 Drulák, Petr. 2009. „Malý Čech jde do velkého světa.“ s. 12 in Hospodářské noviny, Názory, 21.10.2009.

${ }^{94}$ Gabal, Ivan. 2011. „Česko v EU: pasivita a bezradnost.“ s. 8 in Hospodářské noviny, Názory, 8.12.2011.

${ }^{95}$ Mocek, Michal. 2011. „Titanic po česku.“ s. 6 in Právo, Publicistika, 15.12.2011; také Hekrdla, Martin. 2011. „Soumrak kouzelníků.“s. 6 in Právo, Publicistika, 15.12.2011.
} 
Haller, Beth a Jessica Bruce - Rahn (2006): „Media labeling versus the US disability community identity: a study of shifting cultural language." Disability \& Society 21(1), s. 61-75. DOI: $\underline{10.1080 / 09687590500375416}$

Holtz-Bacha, Christina (2004): „Germany: How the private life of politicians got into the media“ Parliamentary Affairs 57(1), s. 41-52. DOI: $10.1093 / \mathrm{pa} / \mathrm{gsh} 004$

Johnson-Cartee, Karen (2005): News Narratives and News Framing: Constructing Political Reality. Lanham, MD: Rowman \& Littlefield Publishers.

Karvonen, Lauri (2010): The Personalization of Politics: A Study of Parliamentary Democracies. Colchester: ECPR Press.

Kinder, Donald (1994): „Reason and emotion in American political life“ In Roger Schank a Ellen Kanger. Beliefs, Reasoning and Decision Making. Hillsdale, NJ: Erlbaum, s. 277-314.

Lowery, Shearon a Melvin DeFleur (1995): Milestones in Mass Communication Research: Media Effects. 3rd ed. New York: Longman Publishers.

Machill, Marcel, Sebastian Köhler a Markus Waldhauser (2007): „The Use of Narrative Structures in Television News: An Experiment in Innovative Forms of Journalistic Presentation.“ European Journal of Communication 22(2), s. 185-205. DOI: $10.1177 / 0267323107076769$

Marx Ferree, Myra, William Gamson, Júrgen Gerhards a Dieter Rucht (2002): „Four Models of the Public Sphere in Modern Democracies" Theory and Society 31(3), s. 289-324.

Mazzoleni, Gianpietro a Winfried Schulz (1999): „Mediatization of politics: A challenge for democracy“. Political Communication 16(3), s. 247-261. DOI: 10.1080/105846099198613

Mazzoleni, Gianpietro (2000): „A return to civic and political engagement prompted by personalized political leadership?" Political Communication 17(1), s. 325-328. DOI: $\underline{10.1080 / 10584600050178915}$

McAllister, Ian (2007): „The personalization of politics.“ In: Russel Dalton a Hans Klingemann (eds.), The Oxford Handbooks of Political Science: The Oxford Handbook of Political Behaviour. E. Oxford: Oxford University Press.

McCombs, Maxwell (2009): Agenda Setting: Nastolování agendy: masová média a veřejné mínění. Praha: Portál.

McCombs, Maxwell a Donald Shaw (1972). „The agenda-setting function of the mass media.” Public Opinion Quarterly 36(2), s. 176-187.

McLaughlin, Lisa (1993): „Feminism, the public sphere, media and democracy.” Media, Culture \& Society 15(4), s. 599-620. DOI: $10.1177 / 016344393015004005$

McLaughlin, Lisa (1999): „Beyond 'Separate Spheres': Feminism and the Cultural Studies/Political Economy Debate.” Journal of Communication Inquiry 23(4), s. 327-354. DOI: $\underline{10.1177 / 0196859999023004003}$

Nečas, Vlastimil (2006): „Agenda-setting: teoretická východiska.“ In: Daniel Kunštát (ed.) České veřejné mínění: výzkum a teoretické souvislosti. Praha: Sociologický ústav AV ČR, v.v.i, s. 79-89.

Nečas, Vlastimil (2007): „Constitutional debate in the Czech Republic.“ Pražské sociálně vědní studie. Mediální řada. Prague: Faculty of Social Sciences, Charles University.

Nečas, Vlastimil (2009): „Mediální kontext české zahraniční politiky.“ In Michal Kořan (ed.), Česká zahraniční politika v roce 2008: analýza ÚMV. Praha: Ústav mezinárodních vztahů, s. 12-29.

Nečas, Vlastimil a Lenka Vochocová (2010): „Média a politika: zahraniční zpravodajství českých médii““. In Michal Kořan (ed.), Česká zahraniční politika v roce 2009. Praha: Ústav mezinárodních vztahů, s. 41-61.

Nečas, Vlastimil a Lenka Vochocová (2011): „Mediální kontext české zahraničí politiky“. In Michal Kořan (ed.), Česká zahraniční politika v roce 2010. Praha: Ústav mezinárodních vztahů, s. 33-57. 
Noelle-Neumann, Elisabeth (1993): The Spiral of Silence. Chicago, London: University of Chicago Press.

Reese, Stephen (2007): „The Framing Project: A Bridging Model for Media Research Revisited.“Journal of Communication 57, s. 148-154. DOI: 10.1111/j.1460-2466.2006.00334.x

Reese, Stephen, Oscar Gandy a August Grant (2001): Framing Public Life: Perspectives on Media and Our Understanding of the Social World. Taylor \& Francis Group.

Reifová, Irena (ed.) (2004) Slovník mediální komunikace. Praha: Portál.

Richards, Barry a Gavin Rees (2011): „The management of emotion in British journalism.“ Media, Culture \& Society. 33(6), s. 851-868.

Shoemaker, Pamela (1989): Communication Campaigns About Drugs: Government, Media, and the Public. Routledge.

Shoemaker, Pamela a Stephen Reese (1996): Mediating the message: theories of influences on mass media content. Longman Trade.

Steuter, Erin (1990): „Understanding the media/terrorism relationship: An analysis of ideology and the news in Time magazine." Political Communication, 7(4), s. 257-278. DOI: $\underline{10.1080 / 10584609.1990 .9962902}$

Strauss, Anselm a Juliet Corbin (1999): Základy kvalitativního výzkumu. Boskovice: Albert.

Swanson, David a Paolo Mancini (1996): Politics, Media and Modern Democracy: An International Study of Innovations in Electoral Campaigning and their Consequences. Westport, CT: Praeger.

Trampota, Tomáš a Vlastimil Nečas (2007): „Intermediální agenda českých médií.“ Naše společnost, 5(2), s. 12-19.

Tuchman, Gaye (1978): Making news: a study in the construction of reality. London: Free Press.

Van Aelst, Peter, Tamir Sheafer a James Stanyer (2012): „The personalization of mediated political communication: A review of concepts, operationalizations and key findings." Journalism, 13(2), s. 203 221. DOI: $\underline{10.1177 / 1464884911427802}$

Vliegenthart, Rens, Hajo Boomgaarden a Jelle Boumans (2010): „Changes in political news coverage: Personalization, conflict and negativity in British and Dutch newspapers.“ In: Kees Brants a Katrin Voltmer (eds.), Political Communication in Postmodern Democracy. London: Palgrave Macmillan.

Vochocová, Lenka a Vlastimil Nečas (2012): „Mediální kontext české zahraniční politiky“ In: Michal Kořan a Ondřej Ditrych (eds.) Česká zahraniční politika v roce 2011: analýza ÚMV. Praha: Ústav mezinárodních vztahů, s. 40-63.

Vreese de, Claes (2005): Framing Europe. Amsterdam: Het Spinhuis.

Wanta, Wayne (1997): The Public and the national agenda: how people learn about important issues. London: Lawrence Erlbaum Associates.

Weaver, David, Maxwell McCombs a Donald Shaw (1998): „International Trends in agenda-setting Research.” In Holtz-Bacha, Kristina (ed.): Wie die Medien die Welt erschaffen und wie die Menschen darin leben. Opladen/Wiesbaden: Westdeutsche Verlag GmbH, s. 189-203.

Zoonen van, Liesbet (2004): Entertaining the Citizen. Lanham, MD: Rowman and Littlefield. 
Vlastimil Nečas, Lenka Vochocová: Česká média a zahraniční politika

\section{Czech Media and Foreign Policy: Emotions and Domestic Narratives}

\section{SUMMARY}

The paper presents key findings of research on the media coverage of foreign policy in Czech news programs, dailies, and magazines between 2008 and 2011. The research aims were twofold: to describe the state of the art of media coverage of foreign-policy issues and to identify prevailing frames and major narratives attached to these issues in the media agenda. Using the triangulation of quantitative and qualitative content analysis, the authors had two objectives: first, to identify the composition of main issues and key actors presented in the news programs of three Czech nationwide TV stations, and, second, to reveal the major narratives and prevailing frames of the news agenda.

\section{TV news}

The quantitative content analysis of Czech TV news focuses on a brief description of its two main characteristics: the central topics and the most frequent actors present in the news. Trends in developments of the media agenda vis-à-vis foreign-policy issues are not unambiguous. It is clear that the main topics which dominated the foreign-policy news of Czech TV news were partly influenced by the current events of the given period. Nevertheless, we can identify key trends concerning the choice of key topics and preferences with respect to the presentation of particular actors.

One of the prominent issues which has appeared constantly over the past four years is the Czech Republic's relations to the European Union in the context of economic policy and further integration with the EU. The other leading issues reflect topical, often newsworthy, and high-profile events such as foreign visits and controversies regarding the construction of a military radar base in the Brdy region. As far as the actors are concerned, foreign-policy TV news from the analyzed period was relatively homogeneous across the board of competing stations, with a clear agreement as to who the most important foreign policy actors were. In the majority of cases, these were the leading politicians of the Czech state and, most importantly, the President, the present and former Prime Ministers, and important opposition representatives. The possibility of crossing the threshold of media attention is thus rather limited for representatives of civil society, experts, and foreign actors, to name but a few. The analysis of large data sets spanning long time periods shows that commercial as well as public service TV stations present their audiences with more or less the same media stories with the same actors (Goffman 1963).

\section{Domestication and 'history-matters' framing}

When referring to events related to Czech foreign policy, the media showed a high level of personalization. What is also remarkable is the strongly negative, polarised character of the media foreignpolicy discourse: the researched media present foreign policy as a battleground for the competing interests and influences of particular political subjects; alternatively, it is explicitly described as a victim or hostage of domestic political conflicts. The general adversarial setting of news on Czech foreign policy is often enhanced by war metaphors.

A very frequent media strategy used to inform audiences about foreign-policy events is the effort to explain internationally relevant events to local audiences by specifically contextualising them by emphasizing the history and importance of the Czech Republic and/or by stressing local disputes between individual politicians and political parties. The bias inherent in such framing and its autotelism have intensified so much over the long term that we refer to them as the domestication of foreign-policy events 
in the Czech media. This domestication takes two main forms: a) an explicit 'explanation' of the issue using parallels with national historical events or historical events from culturally similar countries; b) an emphasis on local aspects of a global issue, especially when international events are related to domestic or, alternatively, intra-party politics (even if there is no direct link with the international importance of the event), including an exaggeration of the role of the Czech Republic in the given event by way of metaphors and historical parallels.

In particular, the opinion journalism of the analysed print media in all the covered years was marked by the distinctly schematic manner of its commentary on foreign-policy issues; it used metaphors and comparisons and revived historical traumas of the country and/or region to exert an emotive effect. The formal shape of the texts stressed the polarisation of the debate, while journalistic texts offered a perspective reducing the issues, stances, and characteristics of the actors to simple patterns. The bipolar division of the world, Russia's specific position (which is difficult to integrate it into the 'friend vs. threat' scheme), and the Czech Republic as a country dependent on a strong protector were other long-term and strong frames present in the foreign-policy news agenda of the analysed print media. This trend corresponds with the prevailing polarisation of the political discourse and revives the classical narrative of a world divided into the spheres of influence of the United States of America and the Union of Soviet Socialist Republics from the Cold War. It follows from the logic of this narrative that the Czech Republic's position is presented as that of a dependent country that has to choose the side of the world it wants, and will belong to.

A highly frequent frame of commentaries on individual foreign-policy events is the revival of threats through reference to significant moments of national history. In opinion pieces, Czech historical traumas are always symbolized by a concrete year or other politically important periods (e.g. 1948, 1968, 1989), most frequently to serve as a reminder of a threat posed by foreign enemies (Russia, Germany) or an internal one (the left-wing). 